九州大学学術情報リポジトリ

Kyushu University Institutional Repository

\title{
A Rice Nematode Disease "Senchu Shingare Byo" : I. Symptom and Pathogenic Nematode
}

Yoshii, Hazime

Laboratory of Plant Pathology, Department of Agriculture, Kyushu University

Yamamoto, Shigeo

Laboratory of Plant Pathology, Department of Agriculture, Kyushu University

https://doi.org/10.5109/22625

出版情報 : 九州大学大学院農学研究院紀要. 9 (3)，pp.209-222，1950-01. Kyushu University バージョン：

権利関係 : 
Journal of the Faculty of Agriculture. Kyushū University. Vol. 9, No, 3 January 31,1950

\section{A RICE NEMATODE DISEASE "SENCHÛ SHINGARE BYÔ" "1)2)}

1. Symptom and Pathogenic Nematode

Hazime Yoshil and Shigeo Yamanoto ${ }^{3}$

\section{INTRODUCTION}

Since more than ten years past rice disease with bleached-tip of leaf has come to attention in Kyushu. Out-break of the disease in 1941 caused a serious damage. The senior author, in 1943, attempted to compare this with the "white-tip" of rice in Texas, U.S., which was reported as a magnesium deficiency (Martin 1939). Water culture of rice was schemed to ascertain if the cause of the present rice disorder in Kyushu be a nutrient deficiency, but no satisfactory results were obtained.

An experiment on this disease, schemed by Mr. H. Fukano of Fukuoka Station in 1943, indicated that this might be a seed-borne disease. In August 19:4, the senior author found a few nemic parasite within the pubescence of young panicule of the diseased rice plant. The same nematodes were found afterwards abundantly in the inner side of hulls of ripe grain.

In autumn of the same year, the preparations of the nematode were brought to Dr. T. Yokoo, Nematologist at Suwon Station, Korea, who found, the nematode new to science and named it Aphelenchoides oryzae (Yoshii 1946, Yokoo 1948).

1) Contribution from the Laboratory of Plant Pathology, Kyushu University.

2) A study based on the "Kagaku Kenkyu Hi" received in 1945 and 1946.

3) The authors wish to express their appreciation to Dr. 'T. Yokoo, formerly Nematologist at Swwon Agricultural Experiment Station. Korea, to Mr. H. Fukano of Fulstolar Agricultural Experiment Station, to Mr. Y. Inoue of Saga Agricultural Experirient Station, and to Mr. Ichiro Tanaka of Jokkaido Ayrimaltural Experi. ment Station for their valuable supports for this study. 
A preliminary report was noted on the Agriculture and Horticulture (the Nôgyô oyobi Engei) in 1944, on the present disease, named "Senchû Shingare Byô", which means "Heart blight caused by a nematode" (Yoshii 1944!. A mimeograph printing was sent to the Ministry of Agricuiture in 1946. in which were written some experimental results in connection with the course of infection of the disease and seed disinfection methodhot water treatment of seed, at $52^{\circ} \mathrm{C}$. for 10 minutes, after scaking in water below $20 \mathrm{C}$, for 24 hours.

Satisfactory results were obtained with three years testing, from 1945 to 1947 , with the seed disinfection method writen above to prevent the disease, at each of the seven Agr. Exp. Station in Kyushu.

Dr. E. M. Cralley of Ark. Agr. Exp. Station, U. S., came to the authors laboratory in 1947, to see the present disease of rice which resembled closely the white-tip in Texas. Recently he agreed that the white-tip of rice in U.S. is a nematode disease (Cralley 1949).

\section{Historicai. REvieW}

A nematode disease of rice called "Ufra" in India is one of the most widely known disease of this sort of diseases of rice, which causes brown discoloration of leaves and sheaths (Goodey 1933). It is said that the causal organism, Anguillulina angusta remains in the field with the rice-stub, and attacks the rice plants at the next season.

Kakuta (1915) found a nematode disease of rice in Kumamoto Prefecture, Kyushu. He called it "Kuromomi Byô" which means Black grain disease. The causal organism of this disease which was said to belong in Tylenchus (Anguillulina), resembles closely the causal nematode of "Funen Byô" (Ear blight) of Italian millet reported by Nakano (1916) in the same prefecture. Kakuta infected rice with the millet nematode with success. As is given later, Kakuta's organism would be the same as the present nematode.

Tanaka and Uchida (1941) reported a nematodo disease of rice, found in Sorachi, Hokkaido, which occurred at that time 
mainly in Variety Kairyô Mochi No. 1 (A glutinous rice), and caused a disorder (restriction of growth) of plants. They found a nematode within seed and stub, and reported that the nematode which, according to them, belonged in Anguillulina, might probably be identical to the Ufra's organism or to the Kuromomi Byô's nematode.

Martin (1939) reported that the white-tip of rice in Texas, U. S., was caused by the deficiency of magnesium. Takimoto (1943) reported that the cause of bleached-tip disease in Kyushu might be identical to that of the American white-tip reported by Martin.

Yoshii (1944) named the present disease "Senchû Shingare Byô" (Heart blight caused by a nematode), and reported with mimeograph printing on the causal organism, Aphelenchoides oryzae Yokoo, and on some experimental results on the course of its infection and on the seed treatment to control the disease (Yoshii 1946). The detail description of the nematode was given by Yokoo in 1948.

At the meeting of plantpathologist and entomologist in Kyushu, held at Beppu in November 1947, Inoue (1947) reported on some preventive method for the nematode disease of rice, Fukano and Yokoyama (1947) reported on the distribution of the nematodes on the affected rice plants. It is ascertained by their studies that the nematodes are found on the ears of the affected plants even when their leaves are not affected.

Fukano and Yokoyama (1948) reported at the meeting of the scientists of Agr. Exp. Stations in Kyushu held at Hainuzuka, April 1948 , on the occurrence of the nematode in stub and straw of the affected rice plants. They (1949) reported also on the occurrence of the nematodes on millet and on some weeds, at the meeting the next spring. At this meeting, Nishizawa (1949) reported on the infection of the disease through irrigation water, Yamamoto and Yoshii (1949) on the relation between the rice nematode disease and Ear blight of Italian millet. Goto and Fukazu (1949) reported on the analytical survey of the affected rice plants of the present nematode disease at the meeting of Phytopathological Society of Japan, held at Tokyo, April 1949.

According to Cralley (1949), white-tip of rice of Amcrica was found to be a nematode disease. 


\section{Distribution of the Nematode Disease in Japan}

The present disease spreads widely in Kyushu. Specimens of the affected ears were sent from Kanto, Tokai, and Chugoku Districts. As will be given later, the causal nematode of "A growth restriction of rice" in Hokkaido reported by Tanaka and Uchida is found to be identical to the present nematode.

It may not be errorneous to regard the following rice plant disorders as the present nematode disease: "Hasaki Imochi Byô" means Leaf-tip Blast, "Hasaki Shirogare Byô" means White-tip; these are the diseases without having any definite pathogens, and are said to spread widely in Japan.

\section{SYMPTOM}

The nematode disease of rice is observed both in upland and watered field. Main symptom appears usually after the beginning of elongation growth. Affected leaf shows its odd character before emergence. The tip of the young folded leaf is already pale yellowish green or white, about 2 to $5 \mathrm{~cm}$. in length. With

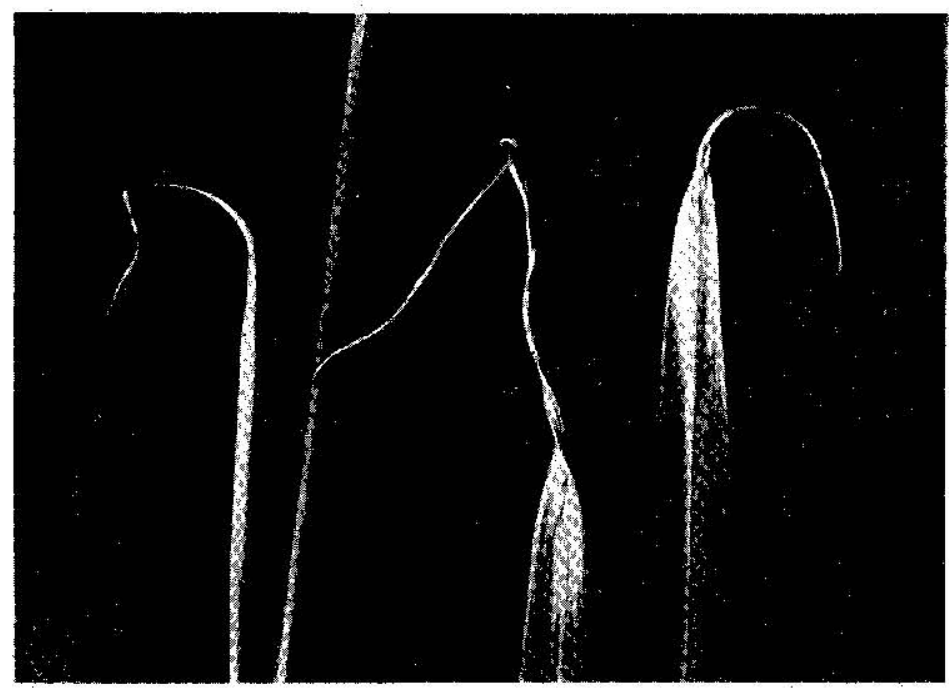

Fig. 1. Bleached-tip symptom of leaves of affected plants. 
unfolded leaf, the discolored part situates usually at the tip of leafblade, seems pale yellow to white or transparent, sometimes indistinctly bordered from the healthy side with a greasy green part (Fig. 1). Later, the discolored part becomes brownish and is torn off by putrescence. Sometimes the bleached part is observed at the portion slightly detached from the tip forming a white band, or is observed at oneside of leaf-blade. In another case, the whole of a discolored area seems greasy pale green. The disorder of leaf is observed on its size too. Especially, flag leaf is considerably shortened and usually whirled and twisted (Fig. 2). In the extreme case the ear comes out from sheath with an abnormal manner due to the deformity of the flag leaf.

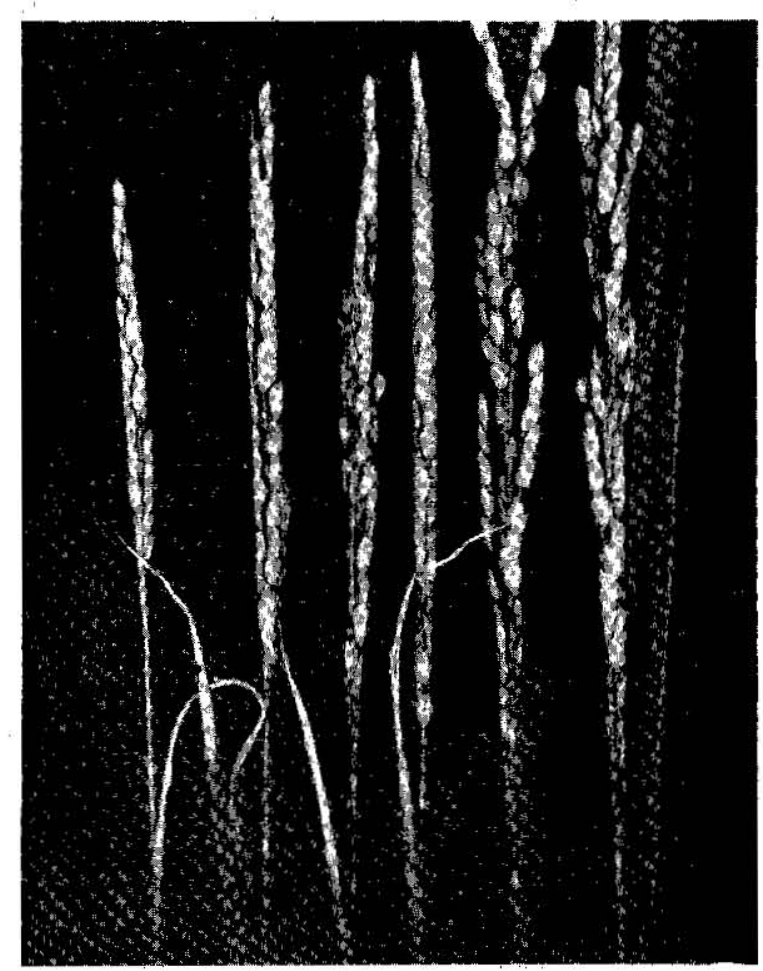

Fig. 2. Shortened and twisted flag leaves of affected plants. Right two are apparent healthy.

It is not common that every leaf of a stem is affected by such disorder, but in many cases the leaves with white-tips are situated 
alternately in a stem. It happens sometimes that the bleached-tip symptoms are invisible completely on the whole leaves of affected plants, though it is the most remarkable symptom of the present disease. In general, the bleached leaf emerges in plenty when nutrition of the affected plant is sufficient, and vice versa. In paddy field in Kyushu, it is inferred that about three times of the numbers of stems with white-tips are affected by the nematode. Occasionally, in a hill, which usually composed of 3 to 5 seedlings, some stems are found healthy while others affected; however as a rule, all of the tillers from one diseased seedling are affected by the nematode.

The affected plants are usually stunted, and have many tillers with leaves dark green in color except the tips of some of them. In case of heavily affected plants, the tillers from higher nodes are often observed. These abnormalities may be the consequence of restriction of elongation growth of stems due to the disease.

Abnormalities in color or in shape of ears are scarcely found; however, ear length is reduced, unhulled-grain is slender, and the percentage of fragmental grain is increased. Examples are given in Table 1 and Table $2 .{ }^{1}$.

Table 1. Charactor of the ear of rice (Variety Shin-Ai) affected by the nematode disease I. Means of 50 measurements each.

\begin{tabular}{|c|c|c|c|c|c|}
\hline & $\begin{array}{l}\text { Length of } \\
\text { stem }\end{array}$ & $\begin{array}{l}\text { Length of } \\
\text { ear }\end{array}$ & $\begin{array}{c}\text { Weight of } \\
\text { ear }\end{array}$ & $\begin{array}{l}\text { Weight of } \\
\text { unhuiled-grain }\end{array}$ & $\begin{array}{r}\text { Weight of } \\
1000 \text { grains } \\
\end{array}$ \\
\hline & (cm.) & $(\mathrm{cm})$. & (gm.) & (gm.) & $(\mathrm{gm})$. \\
\hline $\begin{array}{l}\text { Stems with } \\
\text { white-tip leaves }\end{array}$ & 63.74 & 16.00 & 1.36 & 1.29 & 19.30 \\
\hline $\begin{array}{l}\text { Stems without } \\
\text { white-tip leaves }\end{array}$ & 78.52 & 19.43 & 2.69 & 2.57 & 21.96 \\
\hline
\end{tabular}

Table 2. Character of the ear of rice (Variety Shin-Ai) affected by the nematode disease II. Means of 50 measurements each.

\begin{tabular}{lcccc}
\hline & $\begin{array}{c}\text { Number of } \\
\text { total grain }\end{array}$ & $\begin{array}{c}\text { Number of } \\
\text { normal grain }\end{array}$ & $\begin{array}{c}\text { Number of } \\
\text { fragmental } \\
\text { grain }\end{array}$ & $\begin{array}{c}\text { Per cent of } \\
\text { fragmental } \\
\text { grain }\end{array}$ \\
\hline $\begin{array}{l}\text { Stems with } \\
\text { white-tip leaves }\end{array}$ & 60.96 & 48.36 & 9.32 & 15.29 \\
$\begin{array}{l}\text { Stems without } \\
\text { white-tip leaves }\end{array}$ & 91.06 & 80.24 & 6.96 & 7.64 \\
\hline
\end{tabular}

1) By the courtesy of T. Nishizawa these results were obtained. 
In comparison the bleached part of the affected leaf of the diseased plant to the etiolated tip of an old leaf of healthy plant, it is found that in the latter, browning of vessels is preceded by disintegration of chlorotic area, while in the present discase, the former, necrosis of the vascular bundle tissue is not delayed more than that of the chlorotic area. That is, surrounded with the chlorotic area, which is anatomically normal, the tracheal tubes are often impregnated with wound-gummi and the cells of phloem portion are disintegrated followed by discoloration of cell-membranes.

Hypoplastic growth of cells of the bleached part is generally observed on half unfolded leaves. Chloroplasts are scarce or lacking. The growth of cell-wall of the assimilating tissue is hypoplastic and does not form arm-cell. In the extreme case, wound-gum is found in and about the cells of vascular bundle tissue, and necrosis is also observed in the midst of the chlorotic region. In some cases, growth of motor-cell is remarkably restricted and scarcely be distinguished from adjacent epidermal cells in cross section. In longitudinal section, epidermal long-cell is also reduced in length.

While, on the contrary, following cases are sometimes observed, in which occurs the abnormal enlargement in radial direction of epidermal long- and short-cells and of adjacent cells of mesophyll. This anatomical disorder occurs in the portion corresponding to the part of greasy appearance when the affected leat is observed with naked eye.

\section{Other Leaf Injuries Resembled the Present Disorder}

Although white-tip or bleached-tip of leaf is the main symptom of the present nematode disease, it will also be observed when rice plant is affected by Chlorops oryzae Matsumura. In this case, however, the leaf surface of the affected portion is also wounded.

In Kyushu, a white-tip of leaf is often observed in nursery bed. Sometimes, a leaf blade is withered and etiolated completely. The former disorder occurs in bed with ample water, while the latter in upland or dried bed. Both are the injuries due to a parasitic insect, Eusarcoris ventralis Westwood. The same injuries is said to occur when rice seedlings are affected by Chlorops oryzae 
Matsumura. The white-tip of leaf due to the present nematode disease is uswally found after the beginning of elongation growth.

\section{Pathogenic Nematode}

For convenience the diagnosis of the pathogenic nematode of the present disease given by Yokoo (Yoshii 1946, Yokno 1948) was translated into English as follows:-

\section{Aphelenchoides oryzae Yokoo (1946)}

Body slender. Cuticle very finely striated. Head offset by a constriction. Lips fused, convex. Buccal spear $12 / \%, 1 / 5$ of the

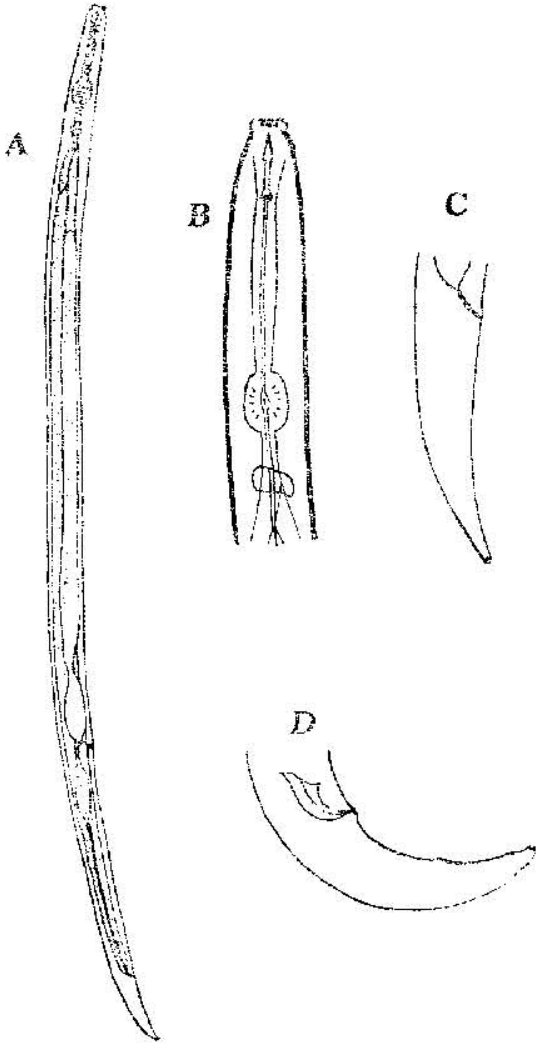

Fig. 3. Cuusal neinatode, Aphclinchoide's oryzae.

A: General feature. B: Head. of female. D: Tail of male. distance of the oesophageal median bulb end from the anterior end of the body, with distinct basal knobs. Anterior oesophageal portion muscular, well developed. Median oesophageal bulb distinct, ellip. soidal. Oesophageal glands in typical position. Posterior oesophageal portion fused with intestine, not distinctly offset. Nerve ring behind the median oesophageal bulb, equal to the spear length. Excretory pore indistinct. Tail conical, tapering, with a star-shaped mucro (trifurcated) at its tip, just as in Aphelenchoides coffeae (Zimmerman) Steiner 1937. Anal opening with prominent swellings.

Ovary prodelphic, not reflexed. Postvulvar uterine sac present, extending $1 / 4$ of the distance from vulva to the tip of the tail. Vulva with no prominent lips. Male 
tail curving to the ventral side ((curvature about $90^{\circ}$ against $60^{\circ}$ in A. olesistus and $180^{\circ}$ in A. ritzema-bosi (Schwartz 1911)). Thiee pairs of copulatory papillae, one pair near the anal opening, a second behind halfways anal opening to tail and the third near to the tip of the tail, post as in A. olesistus (Ritzema Bos 1893), A. pseudolesistus (Goodey 1928, Goffart 1930), A. hodsoni (Goodey 1935), A. ribes (Taylor 1917), A. ritzema-bosi (Schwar1z 1911), A. fragariae (Ritzema Bos 1891), A. parietinus (Bastian 1865), A. helophilus (De Man 1880). No bursa. Spicule curverd, thornshaped, dorsal piece 18 $"$. No gubernaculum (Fig. 3).

Morphological Comparison of the Present Nematode: with THAT OF HokKaido Which CaUSES a Growth Restriction ol Rice, and With the Nematode whrch causes "Kuromomi Byộ" of Rice or "Funen Byô" of Italian Millet

Tanaka and Uchida (1941) reported a nematode disease of a glutinous rice in Hokkaido. By the courtesy of Tanaka the authors obtained the diseased grain yielded in Hokkaido. While, the authors received several ears of Italian millet from Goto, Nagasaki Prefecture, affected by Ear blight (or Funen Byô) $)^{1)}$. As it was unable to find the herbaria of "Kuromomi Byô" or of "Funen Byô", the Goto's sample was used for comparison instead of the millet affected by "Funen Byô" of Nakano. Each nematode of these two sources was compared morphologically with the causal nematode of the present disease.

Both two nematodes of rice of Hokkaido and of Italian millet were reported to belong in Anguillulina. On examination, however, it was found that they belonged under Aphelenchoides because these nematodes satisfied the following characters.

The openings of both dorsal and sub-ventral oesophageal glands situated within muscular bulb. In male, gubernaculum is absent, bursa is absent, three pairs of copulatory papillae are present.

Moreover, these two nematodes closely resembled the present rice

1) A publication on this subject will be given separately. 
nematnde in having trifurcated mucrones at the caudal ends, an in bending habit of tails in male when killed by heat.

Comparison within these three nematodes after Ie Man's formula and after Cobb's formula are given in Table 3 and in Tabie 4 respectively. It is obvious from these tables that there exists scarcely any differences within these three nematodes.

Table 3. Comparison within three nematodes after De Man's formula.

\begin{tabular}{|c|c|c|c|}
\hline & $\begin{array}{l}\text { Aphelenchoides } \\
\text { oryzae }\end{array}$ & $\begin{array}{l}\text { Nematode of } \\
\text { Italian millet }\end{array}$ & $\begin{array}{l}\text { Nematode from } \\
\text { Hokkaicio }\end{array}$ \\
\hline \multirow{6}{*}{ 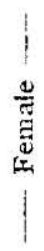 } & Length of body ( $\mu.) \quad \ldots \ldots 650$ ( 504 to 732 ) & $647(575$ to 743$)$ & $766(676.2$ to 853.8$)$ \\
\hline & Width of body $(\mu.) \ldots \ldots \ldots$ I5 ( 13 to 18$)$ & $18.9(16$ to 22$)$ & $13.8(12.7$ to $15 \%$ \\
\hline & a ......................... 43.5 (38.1 to 48.1 ! & $34.6(31.0$ to 39.8$)$ & $51.3(43.1$ to 58.5$)$ \\
\hline & $\beta_{1} \ldots \ldots \ldots \ldots \ldots \ldots \ldots \ldots \ldots \ldots \ldots \ldots \ldots, 6(9.1$ to 12.2$)$ & $9.9(9.0$ to 10.9$)$ & 11.3 ( 10.7 to 12.8$)$ \\
\hline & 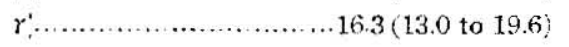 & $18.6(16.3$ to 20.0$)$ & $20.2(18.5$ to 22.9$)$ \\
\hline & 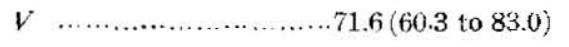 & $71.3(68.0$ to 73.0$)$ & $72.1(70.8$ to 73.7$)$ \\
\hline \multirow{6}{*}{$\frac{2}{\frac{\pi}{2}}$} & Length of body ( $\mu.) \ldots .520(485$ to 600$)$ & $490(456$ to 506$)$ & $563(519.2$ to 627.7$)$ \\
\hline & Width of body $(\boldsymbol{\mu}) \ldots \ldots \ldots, 14 ;, 12$ to 16 ) & $17.3(14$ to 21$)$ & $13.4(11.5$ to 14.3$)$ \\
\hline & a................................ $38.0(33.7$ to 44.0$)$ & $29.1(23.8$ to 34.0$)$ & $42.8(36.3$ to 46.6$)$ \\
\hline & 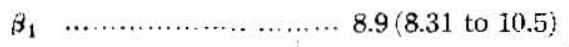 & $8.7(8.0$ to 10.1$)$ & $8.8 \div 8.7$ to \\
\hline & $\ldots \ldots \ldots \ldots \ldots \ldots \ldots .18 .0(13.3$ to 22.0$)$ & $16.9(15.1$ to 19.2$)$ & $17.7(16.1$ to 19.4$)$ \\
\hline & Length of spicule ( $\mu$.) $\ldots$ & 17 & 17 \\
\hline
\end{tabular}

$a=\frac{\text { Body length }}{\text { Body width }}, \quad \beta_{1}=\begin{gathered}\text { Body length } \\ \text { Oesophageal length }\end{gathered}, \quad \gamma=\frac{\text { Body length }}{\text { Tail length }}$.

$V-\frac{\text { Body length }}{\text { Distance from head to vulva }}$

Table 4. Comparison within three nematodes after Cobb's formula.

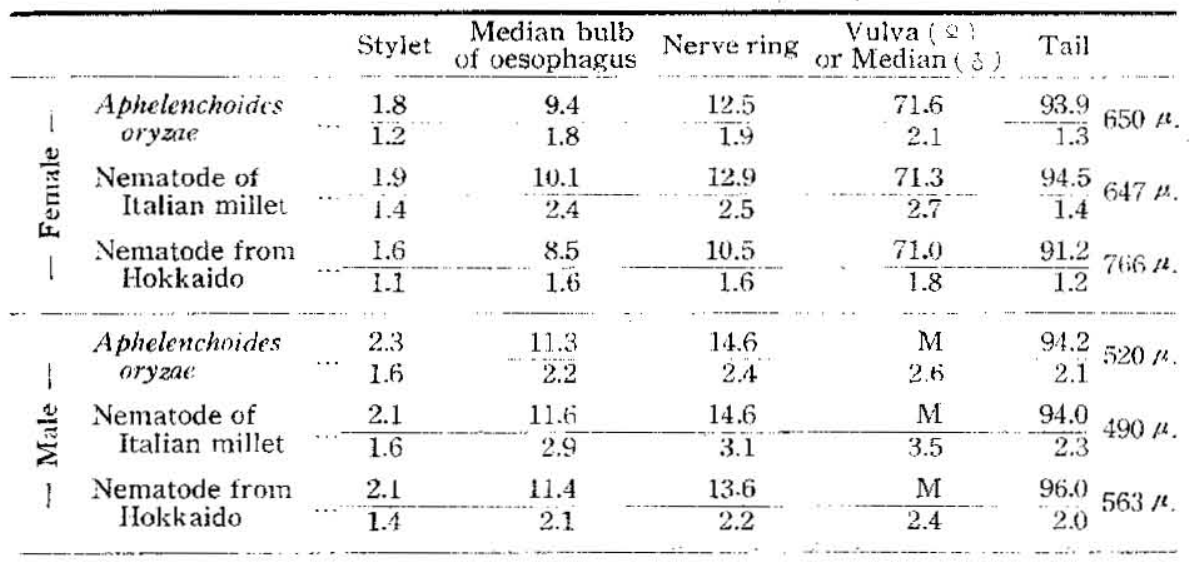




\section{Infection Experiment with Hokkaido Nematode 'TO A RICE VARIETY OF KYUShU}

Rice seed of Variety Asahi ${ }^{\text {t) }}$ disinfected by modified hot water treatment, ${ }^{23}$ and the seed from Hokkaido (not disinfected) were sown separately in May 1948. After the seedlings grew up to a certain height, healthy and diseased seedlings were mixed planted in three pots, $30 \times 30 \mathrm{~cm}$. in size; in each pot were planted five hills of six seedlings each, which were composed of three diseased and three healthy seedlings.

At the beginning of August, bleached leaves were found on the plant of Kyushu variety (Asahi), while no such disorder was observed on Hokkaido variety, a glutinous rice named "Nôrin Mochi No. 1". The rice (Asahi) separated from the diseased seedlings for control, was not affected by the nematode.

After harvest, unhulled-grains of these planis were examined by a method ${ }^{3 ;}$ to count the nematode numbers. The results were given in Table 5. From data in this table it is obvious that the nematode of glutinous rice in Hokkaido is able to infect the rice variety of Kyushu (Asahi), and causes the white-tips of leaves.

Table 5. Nematude numbers within unhulled grains of Asahi mixed planted with the diseased rice plant from Hokkaido. Totals of 25 counts of 10 grains each.

\begin{tabular}{|c|c|c|c|c|c|}
\hline & \multicolumn{3}{|c|}{$\begin{array}{l}\text { Asahi mixed-planted } \\
\text { with a Holikaido variety }\end{array}$} & $\begin{array}{c}\text { Hokkaido } \\
\text { variety only } \\
\text { average of } 3 \text { pots }\end{array}$ & $\begin{array}{c}\text { Astahi only } \\
\text { (Check) }\end{array}$ \\
\hline Nematode living & 3 & 6 & 17 & 102 & 0 \\
\hline Nematode dead & 44 & 26 & 28 & 94 & 0 \\
\hline Total & 47 & 32 & 45 & 196 & 0) \\
\hline
\end{tabular}

1) An old rice variety wirlely spread in Kyushu, in which the present disease is often observed.

2) Immersed in hot water, 7 minutes at $51^{\circ} \mathrm{C}$, after soaked in water for 18 hours at $20^{\circ} \mathrm{C}$.

:3) Ten to twenty unhulled-grains are stripped of their husks. Materials thus obtained are put in a test tube, into which one cc, of distilled water is poured. Thus about 20 tubes are prepared for one lot. After kept at $25^{\circ} \mathrm{C}$. for 16 to 20 hours, the materials in each tube are poured into a watch glass. The numbers of both moving (living) and immobile (deacl) nematode are counted under a binow ular microscope. The number of living nematode counted by this method may be somewhat smaller than expected. 


\section{INFECTYON EXPERIMENTS WITH Aphelenchoides oryzae to Italian Millet}

Though the experiments on infectivity of the nematode of Italian millet from Goto to rice have not been undertaken, Aphelenchoides oryzac was tested with success to infect Italian millet, obtained from Kikyogahara Station, Nagano Prefecture. In case of the experiment in 1946, almost all of ears of the Italian millet sown mixed with the diseased rice in four plots, were affected by the nematode. While no nematode was found in the ears of the millet sown separately.

The symptom of the affected millet is obscure, and could only be found the faint purple specks on the glumes. The symptom is similar to that of "Funen Byô" or Ear blight of Italian millet from Goto. The number of the nematode found on the ear of the infected millet is, in general, exceedingly larger than on the ear of affected rice. It seems likely that the nematode inhabits more easily on the millet than on rice. The numbers of ears of the Italian millet, the third generation from the infected parent, in which the nematodes were found, were given in Table 6.

Table 6. Numbers of ears of Italian millet, the third generation from infected parent, which have the nematode.

\begin{tabular}{lrrrrrrrrrr}
\hline Replicates & 1 & 2 & 3 & 4 & 5 & 6 & 7 & 8 & 9 & 10 \\
\hline Lars with nematode & 9 & 7 & 10 & 7 & 7 & 9 & 9 & 9 & 9 & 10 \\
Lars without nematode & 1 & 3 & 0 & 3 & 3 & 1 & 1 & 1 & 1 & 0 \\
Total & 10 & 10 & 10 & 10 & 10 & 10 & 10 & 10 & 10 & 10 \\
\hline
\end{tabular}

In the back inoculation test, in 1947, from the infected Italian millet to rice, all 25 rice plants used were infected with the disease, each having the leaves with white-tips.

It is affirmed, by the experiments written above, that the nematode from Hokkaido reported as the causal organism of a rict disorder is identical to the present nematode, Aphelenchoides oryzae, that the rice nematode infects readily Italian millet and causes the same symptom of "Funen Byô" from Goto. 
If it is certain that "Kuromomi Byô" of rice is caused by the same nemic parasite of "Funen Byô" of Italian millet (Kakuta 1915), it may be reasonable to note that "Kuromomi Byô" of rice is the same as "Senchû Shingare Byô" or Heart blight of the present authors.

\section{SUMMARY}

Since more than ten years past a rice disease with bleached. tip of leaves has come to attention in Kyushu. The disease is observed both in upland and watered field.

The bleached-tip symptom appears usually after the beginning of elongation growth. The tip of leaf about 2 to $5 \mathrm{~cm}$. in length becomes pale yellowish green to white or transparent. Later the discolored part becomes brownish and is torn off. The affected leaf is considerably shortened and usually twisted at its apical portion. Commonly, the leaves with bleached-tips or white-tips are situated alternately on a stem. Sometimes, however, the bleached-tip symptoms are invisible on the whole leaves of affected plants.

In paddy field in Kyushu, it is inferred that about three times of the numbers of stems with white-tips are affected by the pathogen.

The affected plants are usually stunted, and have many tillers with dark green colored leaves. The tillers from higher nodes are often observed.

The length of ear of the affected plants is reduced, unhulledgrain becomes slender, the percentage of fragmental grain is increased. Ten to thirty per cent decrease in yield is inferred.

The present disease spreads widely in Japan, from Hokkaido to Kyushu.

The causal nematode, Aphelenchoides oryzae Yokoo, is characteristic in having star shaped, trifurcated mucro at its tail end, and in bending habit of tail end in male when killed by heat. Diagnosis of the present nematode is given. 


\section{LITERATI:RI: Cited}

Cralley, E. M.. 1949, Phytopath., 39, 5 (ahstr.).

Fukano, ll., Yokoyama, S., 1947, 14th annual meeting of Plant Protection Soc. Kyushu, at Beppu, Nov. 1447, (Speech).

- . . ...... 1948. Proced, of the Meeting of Agr. Res. Workers in Kyushu, No. 2,20 .

$-\cdots,-\cdots$, 1949, ditto, No. 4, 5.

Goodey, T., 1933, Plant Parasitic Nematodes, London.

Goto, K., Fukazu, R.. 1949, Meeting of Phytopath. Soc: Ja1)an. April 1949 (Speechi. Inoue, Y.: 1947, 14th annual meetins of Plant Protection Sor. Kyushu, at Beppu Nov. 1947 (Speech).

Kakuta, T., 1915, Journ. of Plant Protection., 2, 214.

Martin, A. I., 1939, Am. Journ. of Botany, 26, 846.

Nakano, K., 1916, Journ. of I'lant Protection, 3, 33, 109.

Nishizawa, T., 1919. Proceed. of the Meeting of Agr. Res. Workers in Kyushu. No. 4, 5 f.

Takimoto, S., 1913, Journ. of Plant Protection, 30, 113.

Tanaka, I., lichida, S., 1911, ditto, 28, 193.

Yamamoto, S., Yoshii, 13., 1949, Proceed. of the Meeting of Agr. Res. Workers in Kyushu, No. 4, 29.

Yokoo, T., 1948, Annals Phytopatl. Soc: Japan, 13, 10.

Yoshii, H., 1944, Journ. Agr. and Horticulture, 19, 981.

-- 1946, Annual rept. on rice diseases, sent to the Ministry of Agriculturt for the year 1945 (Mimeograph printing). 